\title{
THE CAUSATIVE INFIX IN SPANISH VERBS
}

\author{
Ladislao Imaz Fz. de Casadevante \\ ladislaoimaz@telefonica.net
}

\begin{abstract}
Resumen
Estudios de Tipología Lingüistica moderna reconocen al infijo, en lenguas muertas y vivas, como un elemento importante de derivación, especialmente aplicado a verbos. Sin embargo, el infijo ha sido morfológicamante ignorado en español, o cuando menos, confundido con el interfjo o sufjo. Contrariamente a esta corriente de opinión, generalizada en la bibliografia especializada moderna, en este estudio se exponen argumentos, que avalan la aceptación del infijo en español. La limitación de espacio recomienda concentrar la atención en el infijo español causativo - iz-, generalmente malinterpretado como sufijo. Dado que -iz- está colocado frecuentemente dentro de la base de un verbo original, entre la raíz y la vocal temática verbal, la naturaleza de ésta última determinará el valor morfológico perteneciente al afijo $-i z-$-. Por consiguiente se impone un análisis en profundidad de esta vocal temática, para concluir la existencia de los infijos causativos en verbos españoles.

PALABRAS CLAVE: Derivación morfológica, Infijo, Interfijo, Sufijo, Vocal temática.
\end{abstract}

\begin{abstract}
In accordance with studies of modern Linguistics Typology regarding the infix, it has been recognized in many ancient and existing languages as an important derivation tool particularly applied to verbs. However, the Spanish infix has been morphologically ignored, if not mistaken with the interfix or the suffix. Against this general trend of thought, reflected in the existing literature, the author has developed arguments for the acceptance of the infix in Spanish. Space limitations recommend concentrating the efforts of the present study only on the $-i z$ - Spanish causative infix, generally misinterpreted as suffix. Since $-i z-$ is often placed inside the base of an original verb, between the root and the thematic vowel, its nature will be fundamental to determine the morphological value granted to the $-i z-$ affix. Consequently a thorough analysis of the verbal thematic vowel is required within this paper to complete the theoretical analysis for the existence of the causative infixation in Spanish.
\end{abstract}

KEY WORDS: Morphological derivation, Infix, Interfix, Suffix, Thematic vowel.

\section{Introducción}

The present paper analyzes the existence of the Spanish causative verbal infix, and the reasons supporting it. The frequent presence of the infix in other languages is a well defined structure through Linguistic Typology (Sapir, 1991: 86)' (Moravcsik, 2000: 548) since 1879, when Saussure explained the infixation mechanism (García Teijeiro, 1970: 7). The infix, however, has been systematically ignored in Spanish, because either its affix nature has been denied (Bajo 1997: 35), or its linguistic entity has been considered as unimportant (Almela, 1999: 184), or finally it has been simply misunderstood in practice with the interfix (Lang, 1997: 26-28), suffix (Martínez Celdrán, 1978: 459; Rebollo Torío, 1991:

1 The quoted bibliography refers very often to Spanish editions, because of their availability at the moment of writing the paper. Moreover, since the study covers Spanish language theories, original quotations in Spanish have been maintained. 
405; González Ollé, 1992: 100; Pena, 1993: 220-1; Rifón, 1997: 19) or a 'suffixal complex' -iz- + -ar- (Sáez Godoy y Wagner, 1992: 29 y 1993: 97). Malkiel (1974: 304) himself was confused in this respect until he reacted and revised his considerations, which are to be held as the foundations for the nature and existence of the Spanish infix.

In the Gramática Descriptiva de la Lengua Española known as canonical, no relevant entity is granted to the infix since its only reference in the table of contents mentions ( $>$ interfijo) (Bosque y Demonte (eds.) 1999: 5132); and in the chapter covering the interfixes (Portolés Lázaro 1999: 5041-5071) no mention whatsoever is made to the infixes. On the other hand, the latest DRAE Diccionario de la Lengua Española cannot be considered as accurate as it should be on the Infix definition, when it says: "Se dice del elemento que con diversas formas se inserta en el interior de una palabra", and unfortunately but certainly makes a mistake at the time of mentioning as example "hum(ar)eda" (DRAE, 2001: 1273). Same more or less confusing concepts are developed: a) in the most recent Morphology Treaties such as Almela's (1999: 161) when it refers to infix as one of the many names given to interfix, or Lang's (1997: 26-28) when it makes the wrong exemplification of the concept by quoting an interfix; b) in the Philological Terms Dictionaries, falling into the same wrong application (Lázaro Carreter, 1990: 237-238); c) in Modern Linguistics Dictionaries (Alcaraz Varó y Martínez Linares, 1997: 301; Dubois et alii 1992: 350; Abraham, 1981: 253; etc.) since none of them provides an accurate and complete notion of the Spanish infix, by means of a correct definition and example.

Therefore, the basic question, is: Do Spanish infixes exist? Are they in nature, form, function and position different from the interfixes? In this respect, the Encyclopedia Britannica Online (2005) has a quick answer, under the Infix reference, defining the infix position and productivity, "between the verbal root and the conjugation marker, are common", which confirms below: "The Greek verbal infix $-i z[. .$.$] is particularly popular in modern Romance$ Languages". From this quotation, as well as from other sources, a new consideration pops up: Is it acceptable the derivation form $-i z-$ as infix, with a prevailing causative semantic value in relation verbs, derived from the affix expressed in the Greek etymon $-1 \zeta$-, within the verbal endings $-1 \zeta-\omega$ ?

\subsection{Study boundaries}

The present analysis of the Spanish infixation will deal only with this affix $-i z$ - form, because of space limitations, without referring to other verbal Spanish affixes, particularly $-e c$ - derived from the Greek etymon - $\sigma \kappa-$, and -e- and -ific-.

After considering all previous comments, revealing such a confusion concerning the name, concept and example of the Spanish infix, it results mandatory to examine the up todate existing literature on this respect. Only after concluding its study it will be possible to obtain an overall view, and to formulate a coherent Spanish infix definition, which should be checked as to its application in the language, against a well developed corpus of original and infixed verbs, in which it may be possible to confirm the previously established existence, nature, form, function and position for the mentioned infix ${ }^{2}$. 


\section{The infix}

\subsection{Revision of the a) name and b) concept of the Spanish infix}

a) It is appropriate to distinguish between the infix name and concept, because Malkiel himself recognized in 1949: "I was still operating with a gratuitous extension of the category of infix" (1974: 304). In fact, at that time, he was referring to the interfixes, wrongly applying to them the name of infixes, until $\mathrm{H}$. Lausberg, the real 'father' of the interfixes criticized him in this respect. Ever since, Malkiel (1958: 108) would become a referent for interfixes, and in the process to explain them as compared to other affixes, he defined the infix. In this regards, Malkiel pointed out with precision its first formal appearance in Romance languages, mentioning a study of 1878 by Nigra, in which the Italian linguist studies the elements - $a z_{-},-i z-,-o z-$ found in the jargon Canavese verbs. Is this a fore-runner Romance expression of our -iz- infix? Consequently, we have a very short perspective in Spanish to analyze comments on the infix existence and characteristics.

The infix has always existed from old days in languages which incorporated it to their morphology, though the explicit term, by means of a denomination different form the generic 'suffix', does not appear in linguistic typology up to the XIX century. Karl Brugman signed the foreword to his first volume of $A$ Comparative Grammar of the Indo-German Languages in Friburg in $1887^{3}$.

Brugman (1887 $: 188)$, while talking about the syllabic root ending in either explosive or aspired consonant in Indo-German languages, explicitly recognized that the incorporated nasal could be, depending on the cases, suffix or infix. Along its analysis, Brugman was referring himself to the 'guru' of the Indo-European studies, and first defender of the infixes August Fick, quoting him (Brugman 1887': 137, foot-note 3), regarding his appreciation for the infix, as the "oldest and most powerful agent which causes word grow out of word".

For a quick review of the Spanish literature on the infix, the compiled guides under the umbrella heading "Word Formation" are of help, such as the ones by Joaquín Garcia Medall (1995), Ignacio Bosque y José A. Mayoral (1979), Paul M.Lloyd (1963-64), and Franz Rainer (1993), in which, nevertheless, there are very few references explicitly studying the infix, and quite a few, misunderstanding the infixes with other affixes, particularly interfixes. In order to avoid duplication of separate quotations in regards to the name and concept of the Spanish infix, both terms will be presented under the next section.

b) Malkiel's contribution (1958: 108) is fundamental, since with authority and precision, but furthermore with precedence in order of time, he has defined the infix saying that it "implica el concepto de un inserto dentro de un cuerpo estrechamente unido", and showing examples which will help later as advance arguments to support my thesis: "por lo tanto, parece apropiado emplear el término al tratarse [...] de flore-sc-o frente a flore-o; acaso también al contrastar, con menor exactitud, guar-ec-er con guarir en español antiguo" (Malkiel 1958: 109). In confirmation of Malkiel's quote (1958: 109), as infix sample, the $-n$ - in latin iu- $n$-go, similar examples could be added in this respect, as the ones noted by Leumann

3 References to K. Brugman along this paper will be based on the English version, published in India in 1972. 
(1977: 533): vinco, relinquo, rumpo, fundo, tango, frango, nancor, pungo, tundo, etc., because as Chantraine (1983: 143) says: "The Indo-European language had a-thematic present forms characterized by an infix nasal element", and Brugman (1887 : 136-40) in chapter D, Classes XII to XVIII, NASAL PRESENT STEMS talking about Indo-arian languages, mentioned this form, which passed to Greek, though in its most archaic expressions. In the same fashion as Malkiel quotes the -sc-infix in the Latin flore-sc-o, Chantraine (1983: 148) speaks of the Greek suffix - $\sigma \kappa-$ with a polysemic, iterative, inchoative, durative and final value, which with additional semantic values, can be traced among other languages up to Indo-Iranian, Armenian, Hitite. In this respect, the latest as well as the first complete study of the mentioned infixal group in Romance languages has been presented under the form of Doctoral Thesis by Elvira DiFabio (1990), covering it in the Latin -sk-expression, transferred as such into the Proto-Romance languages such as the Italo-Romance (characterizing Italian, Italian dialects, Catalan, Rumanian), Gallo-Romance (French, Provençal) and IberoRomance (Spanish, Galician, Portuguese).

The Spanish Language Academy Dictionary is of no help in the definition of infix. The DRAE in its latest edition, as already mentioned, remains with an imperfect definition at the etymological threshold of the term, unfortunately adding an error to the example. The linguistic dictionaries too add confusion to the subject, as the one by F. Lázaro Carreter (1990: 237-38), defining infix, with almost identical words, and with the same wrong example, as used in the DRAE (2001: 1273). That is why neither one hesitates at the time of recording the entry interfix and referring it surprisingly to infix (DRAE, 2001: 1291; F. Lázaro Carreter, 1990: 243).

I omit quoting again the previously mentioned Linguistic Dictionaries. The only one worthwhile mentioning is Marouzeau's (1969: 121) which correctly but sparsely, and avoiding any commitment as to its semantic value, defines the infix with the help of a really valid example, the $-n$ - of iungo. Leaving Dictionaries aside, it should be recognized that the Gramática Descriptiva de la Lengua Española (Bosque y Demonte (eds.)1999), as already seen, grants still less linguistic entity to the infix.

\subsubsection{Analysis of the studies on the Spanish infix}

In view of the confusion developed around the infix, it seems necessary to get hold of the scarce monographic studies on interfixes/infixes in order to compare ideas and substantiate the position I will finally adopt for the infix. There is only one book entirely devoted to the interfixation written by Martín Camacho (2002), with an exhaustive and deep analysis of the Spanish interfix, whose existence he finally denies (2002: 235), and practically with no mention whatsoever to the infix. He includes it as passing by among the different affixing types, with examples from Chamorro and Sudanese languages, and concluding that "los términos interfijo e infijo, aluden a realidades similares, pero no iguales, por lo que conviene, aunque sólo sea por el bien de la claridad expositiva, mantener ambas denominaciones plenamente separadas" (Martín Camacho, 2002: 36). It is my opinion that infixes differ from interfixes in nature, form, function and position, as summarized and shown in the comparative summary chart. The only similarity which could bind them together would be their belonging to the affix field, provided that the interfix complies with the affix requirements. 
Lázaro Carreter, in his study "Sobre el problema de los interfijos" (1980), discusses them with Malkiel, but without mentioning the infixes, except in one instance, quoting them as eventual synonyms of the interfixes, "como, indistintamente, los llaman otros lingüistas" (Lázaro Carreter, 1980: 11). No wonder that from the very first edition of 1953 of his mentioned Diccionario de Términos Filológicos, Lázaro Carreter will always say as example for infix one of the traditional interfix examples, hum-ar-eda (1990: 237-8).

At an early date chronologically speaking of specific literature on infixes, Bernard Pottier wrote an article on "Los infijos modificadores en portugués" (1953). The linguistic proximity with the Portuguese could promise an easy transfer of concepts and examples into Spanish. But the nomenclature used by Pottier does not correspond to the concept or to the perspective of the infix term, as used after its formulation by Malkiel. For this reason, I will omit details concerning Pottier's work, based mainly on Knud Togeby's, Structure immanente de la langue française, in which the words are considered to be formed with "theme + flection", i.e. root plus one or two derivatives. The homogeneous derivatives, which do not imply syntactic change, are modifier infixes with a semantic value of quantitative expression for the same base, "pobr-et-ão". On the other hand the heterogeneous verbalized infixes may change the class of the base, like in "verd-ec-er". According to Pottier, the modifier infixes go always behind the root and correspond, within the nominal or deadjetival categories to the augmentative or diminutive processes (ri-ach-o), and the heterogeneous verbalized infixes determine particular categorizing form $(-i z-+-a r,-e c-+-e r,-e-+a r)$. At the end, Pottier leaves the consideration concerning the infixes open, while saying: "Hay que desprenderse absolutamente del valor actual, momentáneo, y seguir el MOVIMIENTO evocado por el infijo, el cual se perfila, entre otras cosas, por las pruebas de conmutación" (Pottier, 1953: 185).

Miguel A. Rebollo Torio published a specific article on the topic "En torno a los infijos" (1984), generating certain confusion, since at the time of analyzing the word's internal structure, he takes cover into the various authors' opinions, unifying the morphological phenomena that may happen as infixes and interfixes. Along the article the author mentions continuously the term infix, and illustrates it with examples belonging to the interfixes (Rebollo Torío, 1984: 311).

The definition provided on the infixes is worked out by an exclusion process, through contraposition to prefixes and suffixes, describing the infixes position inside the word which they cannot neither initiate nor close, denying to the infixes the grammatically modifying capacity, and recognizing them a limited phonic body. Although Rebollo Torío correctly asserts that "Hay dos aspectos en los que hay que detenerse por fuerza y que constituyen el centro de las polémicas suscitadas por los infijos: su función y su significado" (1984: 313), it is interesting to mention that in order to support it, he recalls the $20^{\text {th }}$ edition DRAE, defining "Infijo: Afijo con función o significado propios, que se introduce en el interior de una palabra" (DRAE, 1984: 771). Unfortunately the latest 2001 DRAE edition (see p. 254 of this study) does not maintain any more the 1984 definition, identical to the previously mentioned in the 1970 DRAE. Rebollo Torío displays an array of knowledge and wisdom analyzing the increments for the diminutive suffixes, but falls short in the analysis of the infix, confusing it with the interfix.

In the polemic analysis of the interfix characteristics presented by Alvar and Pottier, Rebollo Torío mediates commenting the criticism made by Lázaro Carreter to Malkiel, and 
tackles directly the interfix, but falls into the problem he is judging: "la doctrina académica produce cuando menos perplejidad al crear contradicción entre lo que define bajo la etiqueta de infijo y la práctica" (Rebollo Torío, 1984: 313). Any additional comment on this article and author may be summarized in his denial of difference between infix and interfix, as he binds the incidence of the infixes to the diminutives.

Consistent with the above Rebollo Torio never analyzes, in his second article (1991), possible interpretations and components of the nature of verb ending morph -izar. Besides my disagreement with many of the -ar/-izar verb couples he presents, since they do not share neither the same 'theme' nor the same source, I do not accept, according to my reasoning to be exposed later, Rebollo Torío's scheme (1991: 405) when he states in the first line of the article that -izar is a suffix.

Sylvia Faitelson-Weiser (1949: 146-7) mentions the Malkiel interfixes at the time of making an analysis of the phonetic suffix increments, and associates them in form and purpose. Considering that her exposition is merely concerned with phonetic insertions, no wonder the infixes do not appear at all along her study, but only the interfixes.

In a similar way, José Portolés Lázaro in his two very valuable contributions on interfixing (1993 and 1999) analyzes its relations with the phonetic inner mediation, and reaches the conclusion that there are two different subjects altogether. "La interfijación es el proceso de la morfología derivativa por el que se añade una unidad morfológica, que se denomina 'interfijo', entre la base y un sufijo derivativo, o entre la base y la flexión verbal" (1999: 5043). Portolés in his earlier article (1993: 341) granted the morpheme value to the interfix “ya que cumple la condición de ser una unidad mínima reconocible en el análisis gramatical". In Aronoff's opinion the essential portion of the morpheme is not its meaning, but its possibility of recognition by us. Following this path Portolés has departed from Malkiel's empty morph and from Lázaro Carreter's morpheme structuralist concept.

Portolés advises that, at first look, there are derivations that may induce us to discover a process of interfixing, when in reality they hide a double derivation. As a matter of fact Portolés receives the witness of the interfixe existence handed by Malkiel, as belonging to the derivative morphology. Both authors agree in many aspects of the interfixing form, though Portolés methodically adds clarifying or complementary comments: interfixing may be applied to nouns, adjetives and verbs; the interfixing general atony, may accept accent because of exigencies by the flectional verbal form; the interfixes lack the fixed position of the suffixes; the interfixing admits interfixe chain. There are very clarifying negative considerations made by Portolés and omitted by Malkiel, making the point on what the interfixes are not: elements of suffix chains, and segments as part of patrimonial or loan words.

The interfixing favors the relations between bases and suffixes, but there are also phonetic reasons to introduce phonic elements which are not to be considered as interfixes. "Los interfijos vistos hasta este momento no son fonemas que aparezcan por motivos meramente fonéticos, es decir, no sirven sólo para habilitar secuencias de sonidos de otro modo imposibles" (Portolés, 1999: 5051-2). "Una de las funciones de la interfijación consiste en posibilitar formaciones léxicas vedadas sin ella por motivos morfológicos" (Portolés, 1999: 5055), as happens when it is intended: a) to form derivatives in -ón from $2^{\text {nd }}$. or $3^{\text {rd }}$. conjugation verbs (dorm-il-ón); b) to achieve deverbal adjective derivations by -in (and-ar-ín) or -oso (peg-aj-oso); c) to derive verbs from other verbal base by means of frequentative ending -ear (corr-et-ear); d) to join occasionally the base to the suffix -ón (moc-et-ón); e) to maintain 
the accent of the base, as secondary accent (tiern-ec-illo); f) to facilitate the identification of the base (camion-ci-to); g) to maintain the thematic vowel in the union with suffixes (barr$e$-nd-ero); h) and finally to avoid homonymy (dent-ell-ada).

Intentionally I have developed in a summarized form the detailed and complete description made by Portolés on the interfixes, in order to derive through their understanding a better comparative knowledge on the infixes, in spite of not mentioning them in his study.

In opposition to the presentation made by Portolés on the interfixes, granting them a morphemic and semantic value, and promoting them to the affix derivative rank, Montes Giraldo (1984) takes out the interfixes from the affix category, since he understands that the speaker cannot use them as a detachable element in synchrony. In his publication one year later, under the title "Reexamen con base en los datos del ALEC" (Montes Giraldo, 1985), revises his vision in regards to the interfixes and offers new points of view on them. Nevertheless, nowhere Montes Giraldo mentions the infixes. He only analyzes the polymorphic suffixes, in which two or more suffix morphemes can be considered different, what certainly is marginal to infixation.

The detailed analysis made on the ALEC materials leads Montes Giraldo to the conclusion of the theoretical and practical impossibility to separate 'sterile' elements from the compound suffixes, because it may result into a semantic fading, and simultaneously the loss of its suffix character. The study by Montes Giraldo questions the existence of the interfix, its function as independent morphological category, and finally its semantic content value, but at the same time it is completely silent on the consideration of the infix.

Following the track of the interfixes and searching for analysis or documentation on the infixes, we come across with Wolfgang Ulrich Dressler (1986), who in addition to making an updated inventory of the existing interfix theories, and to exploring different perspectives by mentioning linguistic typology considerations, finally speaks of both kinds of interfixes, presuffix and inter-root, called infixes. For this reason, he makes clear immediately that the infix term is only reserved to affixes inserted within a root and endowed with semantic or grammatical value like the $-n$ - in Latin fra- $n$-go (Dressler, 1986: 382). In accordance with Dressler, the infix breaks into the root, and the interfix is always found between two morphemes. He defines the morph-tactic position of the interfix, between prefix or suffix and root or theme. It is advisable to clarify that root and theme have same value for Dressler, and mean what is known as root.

As a logical follow up to his first work (Martínez Celdrán, 1974) on the suffix introduction morphophonemic rules, which govern the construction of derivations of this type, primarily by means of synchronic laws, four years later Martínez Celdrán (1978) tackles the topic of the infix/interfix.

Wisely in his first work Martínez Celdrán makes an evaluation of synchrony and diachrony, considering both as diverse investigation methods, though finally complementary. As a result, he passes judgment on Malkiel's methods, using a synchronic definition of interfix, and a diachronic method in his research and evaluation (Martínez Celdrán, 1974: 186). No doubt both methods are complementary.

Martínez Celdrán (1978: 447-460) focuses clearly his second study on the infixation subject: "Creo que los conceptos de interfijo e infijo no están suficientemente claros en la literatura lingüística de nuestros días; no solamente están mal definidos sino que además con harta frecuencia se confunden". He next reviews definitions and problems presented by the 
linguists on this subject in Spanish. I will mention for the sake of the present study those definitions and reasons which may be more recent or clarifying in regards to the infix.

After presenting the complete list of authors and terms, Martínez Celdrán takes as starting point a couple of sentences from Malkiel. In the first one he makes the distinction between "un interfijo anterior o postprefijo (en-s-anch-ar), muy raro en español, de un prefijo posterior o antesufijo (polv-ar-eda)" (Malkiel, 1958: 116), and further clears out diferences: el "infijo implica el concepto de un inserto dentro de un cuerpo estrechamente unido; por lo tanto, parece apropiado emplear tal término al tratarse del lat. fingo, frente a figi, y de flore-sc-o, frente a flore-o" (Malkiel, 1958: 109). This infix concept, as per Martínez Celdrán, is not in accordance with the application made at the time by Lázaro Carreter, since while using the polv-ar-eda example, he mistook it with the interfix, since the word *polveda does not exist in Spanish.

The infix is a real morpheme with all its characteristics: possible commutation, semantic value, insertion into an existing word of the language, and belonging to a closed group. The absence of these characteristics belong to the description of interfix, which can be recognized, in a summary of all its negative features, as not belonging to the affix group (Martinez Celdrán, 1978: 450-1), because affixes are morphemes, which modify the category or the meaning of the word or base they are applied to.

One of the most important examples in my opinion are the ones originated from $-s c$ infix, in flore-sc-o since the verb flore-o exists. For Pottier and Malkiel it is an infix, because it is an insert within a word with proper autonomous existence, flore-o. Unfortunately Martínez Celdrán does not make inroads into additional analysis, and detours the attention to other applications of infixes proposed by Pottier, with which Martinez Celdrán does not agree, like for example to consider the form -it- of the diminutive appreciative suffixes as infixes, except within the adverbs (lej-it-os), masculine nouns ending in a (pijam-it-a), and some proper names (Osqu-it-ar).

As a conclusion I am hereby formulating briefly Martínez Celdrán's (1978: 460) opinion concerning the infix, as a terminological variant of the suffix which neither has flection, nor is inserted. I disagree with his statement as being a variant of the suffix.

The infix has more entity than the one granted by Pena (1999: 4326) while saying: "Los 'infijos' son morfos continuos que se insertan dentro de otro morfo, normalmente la raíz, convirtiéndola así en una raíz discontinua". The examples quoted to illustrate his statement are, in Latin the already mentioned nasal appearing in some verbs, and in Spanish some

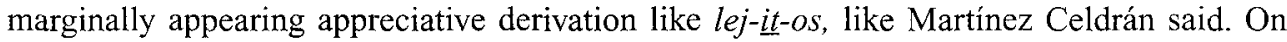
the other hand, contrary to Pottier, Pena recognizes the suffix nature of the appreciative derivation (libr-it-o). Next, I will present my thoughts in regards to the infix.

\subsection{Revised definition of the Spanish infix}

Summing up above mentioned comments, with which I have agreed or disagreed following their trends of thought, I will briefly present the four elements which will be conclusive regarding the infix: its nature, form, function and position.

Nature

The infix is an affix, a morpheme of the "bound" type, and as such including a semantic value with polysemic qualities, as it is a general characteristic of the Spanish affixes. 
The infix syntactically does not change the category of the base to which is joined and, in accordance to which is applied, governed by the base semantic meaning and grammatical category. "An infix is an affix which is positioned inside the base such that the preceeding and following portions are not meaningful by themselves" (Moravcsik, 2000: 545). The infix is a non-independent morpheme, intended to modify semantically the base.

Form

The infix is phonematically structured in a brief and constant manner, which renders it easily identifiable. From the beginning it has been mentioned that, for reasons of space, the present study is restricted to evaluate as infix -iz-, without analyzing for the moment other representative verbal infix Spanish forms such as -ec-, -e- and -ific-.

\section{Function}

The function of the infix is to provide the base, in which it is inserted, with a complementary derivative relational semantic value, added to the patrimonial meaning of the base. It is a good opportunity to remember that this complementary value derives in Spanish from the morphological processes of prefixation, suffixation (appreciative as well as non-appreciative), infixation and para-synthesis. However, at the time of considering a derivative semantic modification of a verbal base, it has to be recognized that the only available procedure in Spanish is through the use of a prefix or an infix, to which eventually a prefix may reinforce the application.

The causativity is one of the most frequent semantic values attributed to morphological elements in many languages (Shibatani, 2001: 4-11), and I may say like the infix. Verbs defined as causatives contain a relation meaning in their semantic structure between entities and actions (Moreno Cabrera, 2003: 170). This relation is expressed either lexically or more commonly morphologically.

It is generally admitted that the Spanish -iz- affix has a predominant causative semantic meaning (Bosque, 1973: 106-7; Aranda, 1990: 163-4; Rebollo Torío, 1991: 408; Pena, 1993: 249; Rifón, 1997: 75; Serrano-Dolader, 1999: 4693), without excluding other interpretations like factitive (Pharies, 2002: 373) or meanings, in accordance with the polysemic semantic value of the Spanish affixes (Bergua Cavero, 2004: 184-5). Because of these characteristics of the -iz-infix I have chosen it, as a base for the analysis of the existence of infixation in Spanish, and for the eventual comparison with other Indo-European and Non-Indo-european languages ${ }^{4}$.

\section{Position}

The above mentioned fundamental function of the Spanish infix is to modify verbal bases, wherefrom new verbs and later on nouns and adjectives may be derived. The position for this modification is categorically fixed between the root and the thematic vowel, namely inside the base or theme, understood by Malkiel (1958: 109) as a "cuerpo estrechamente unido". In linguistic typology "infixes are ordered relative to the beginning of the base much more frequently than relative to the end of the base" (Moravcsik, 2000: 547), position preferred by the Romance languages in general and Spanish in particular.

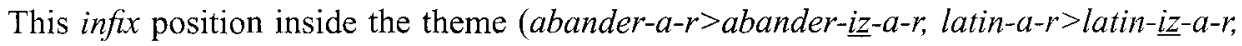

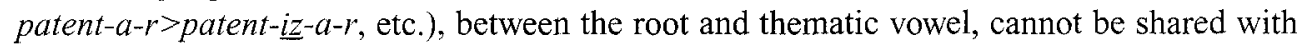
any other affix: the prefix, as the noun indicates, goes ahead of the base; the derivative suffix 
goes behind the base or another suffix, and before the flectional desinence, nominal as well as adjetival; the interfix goes between the prefix and the base or between the base and the suffix; and the circunfix, since it surrounds the base, goes immediately before and after it.

The following summary chart, presents the characteristics of the Spanish infix as compared to the interfix.

\begin{tabular}{|l|l|l|}
\hline Concept & Infix & Interfix \\
\hline Origin & Y. Malkiel & Y. Malkiel \\
\hline Nature & Affix & 'Special affix' \\
\hline Form & -iz-, -ec-, -e-, -ific- & Multiple \\
\hline Function & Derivative Semantics & Morphophonological \\
\hline Position & Inside the root or base & Between base and suffix \\
\hline $\begin{array}{l}\text { Semantic } \\
\text { Value }\end{array}$ & Yes & No \\
\hline $\begin{array}{l}\text { Limitations } \\
\text { Definition by } \\
\text { Y. Malkiel }\end{array}$ & Without syntactic change & Without syntactic change \\
\hline $\begin{array}{l}\text { Example } \\
\text { body }\end{array}$ & Concret-iz-a-r \\
\hline $\begin{array}{l}\text { Accent } \\
\text { of its existence }\end{array}$ & $\begin{array}{l}\text { Ignored } \\
\text { Unmarked }\end{array}$ & $\begin{array}{l}\text { Empty morph between the } \\
\text { root and suffix }\end{array}$ \\
\hline
\end{tabular}

\section{The thematic vowel}

\subsection{Condition for the Spanish verbal infix: the verbal thematic vowel}

In prior sections I have analyzed the need for a morphological derivative process to express additional relation concepts by means of a verbal lexematic unit, and I have defended that the infix is the only means to perform it. The reasons to support this statement must be 
necessarily explained. Without entering into comparisons with other Romance languages, the general opinion admits that in all Spanish verbal forms there is a thematic vowel. If it is not a derivative suffix, and does not form part of the verbal flection, necessarily has to be something else, on which the nature of the infix will be confirmed. In accordance with $F$. Lázaro Carreter (1980: 13) I will define its nature as a 'sub-morpheme', forming with the root a "cuerpo estrechamente unido" (Malkiel, 1958: 109), which therefore will not admit anything else within itself but an infix, since any other affix like a suffix would not respect the derivative composition laws. Let us remember that the derivative suffixes of any kind go immediately after the base (Almela, 1999: 77; Lázaro Carreter, 1990: 382), and before the, nominal, adjectival or verbal flection suffixes. This positioning rules out the suffixation inside the verbal base, because of the presence of the thematic vowel which is at the conclusion of the base. In this way, the apparently irrelevant vowel, with apparently little grammatical protagonism, becomes decisive in the classification or the verbal base constituents. This is the reason for analyzing in the next section the theories and nature of the thematic vowel.

Based on the above, I cannot agree with the opinion that the ending -izar is a verbal suffix (Portolés, 1999: 5053; Rebollo Torío, 1991: 405; Lang, 1997: 217; Urrutia Cárdenas, 1978: 63; Serrano Dolader, 1999: 4709, et alii); or its components -iz-a- (Pena, 1993: 2201), -iz- (Rifón, 1997: 19). In summary I maintain that: $-i z$ - is an infix, $-a$ - is the thematic vowel, and $-\mathrm{r}$ is the infinitive flectional suffix.

\subsubsection{The term 'verbal thematic vowel'}

The citation form of verbs in the Spanish lexematic dictionaries and inverse indexes is the infinitive in which the verbal thematic vowel is placed just before the -r, flectional desinence of the infinitive. Since there are in Spanish three different infinitive endings, corresponding to the verbal paradigms -ar, -er, -ir, the so called verbal thematic vowels are the corresponding $-a-,-e-,-i-$. For brevity sake I will consider only the -a- thematic vowel, because it is the one involved in the verbal derivations to be examined $-i z-\underline{a}-r$. This - $a$ - may appear independently (abanic-a-r) or combined with an affix in the verbal derivation (profet-iz-a-r) (Rifón, 1997: 9), also called immediate or mediate respectively (Serrano-Dolader, 1999: 4685). Whatever I may say concerning the thematic vowel will be valid for either form.

It helps at this point to insist on the verbal citation form in the Spanish dictionaries, disregarding the ancient Greco-Latin form of quoting by means of the first singular person of present indicatif. The departure from this method is not fortuitous, but intentional, because by quoting the infinitive, its base determines the type of conjugation to be followed, and the base for all forthcoming derivations. As mentioned, the verbal base is what remains after the substraction of the infinitive flection desinence $-r$. In here, it is advisable to emphasize that the resulting base including the one expressed in the infinitive remains constant in all derived words and all forms of the verbal paradigm flectioned forms, except, because of Latin influence, in the $1^{\text {st }}$ S. Pres. Ind.; $1^{\text {st }}$ and $3^{\text {rd }}$ S. Pret. Ind.; and all persons of Pres. Subj. On the other hand, the flectional de-nominal or de-adjectival thematic vowel is of different nature, since it is not constant but variable in accordance to the morphological option $-a /-o$ because of change of gender, except in nouns of ambiguous, common or epicene gender, and in accordance to phonetic adjustments to some derivative suffixes. 


\section{COMPARATIVE CHART OF THEMATIC VOWELS}

\begin{tabular}{|c|}
\hline 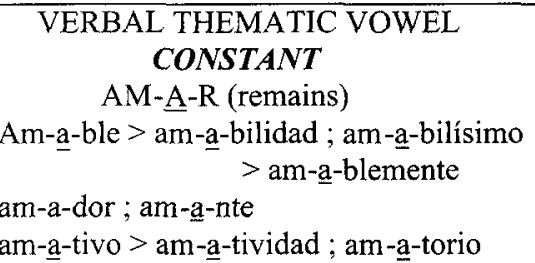 \\
\hline
\end{tabular}

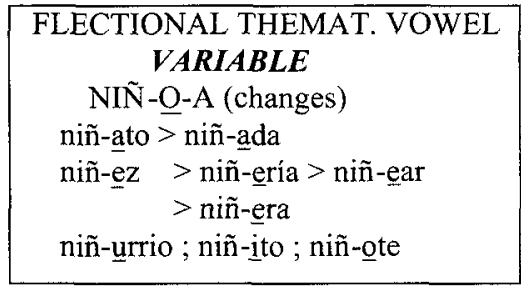

3.1.2. Analysis of literature on the thematic vowel

The opinion variety and even contradiction found in regards to the infix and interfix repeats itself on the verbal thematic vowel. And so, I will repeat the previous method to present and study the up to date opinions, in order to submit finally my considerations in this respect in a coherent way.

I will start saying that the verbal thematic vowel seems to participate, in accordance with various authors, of both a derivative affixal nature and of a verbal constitutive nature. Some argue that the vowel participates of an affix nature, because should it be of flectional nature (Lang, 1997:214), it would not be able to effect a syntactic category change as it does (Rifón 1997: 11) in the process of de-nominal or de-adjectival verbalization, by applying one of the three derivative processes (Pena, 1993: 232): the vowel -a- transforms the nominal base into verbal, although the same phonic constituent is affected in this last instance, and remains apparently constant, but its morphemic nature has varied, because it becomes different after this verbalizing transformation. In spite of this, the verbal thematic vowel is neuter semantically speaking (Serrano-Dolader, 1999: 4688) and consequently "no dota al verbo derivado de una determinada nota de significación, ni en cuanto al proceso en sí (aspectualidad), ni en cuanto al proceso en relación con sus actantes o argumentos (estructura argumental)" (Pena, 1993: 233). No doubt, for these authors the thematic vowel lacks semantic value.

Addition

Substitution

Conversion or

Transformation (perfil > perfil $-a-r)$

$($ vaci $-o>$ vaci $-a-r)$;

$(l i j-a>l i j-a-r)$,

the base chan ges from <denominal/deadjetival $>$ to verbal

The above expressed comments, in regards to a certain derivative affixal participation, are not shared by Lang (1997: 214), because, when he refers to -ar as a productive suffix, he says: "Dado que estos morfemas constituyen un accidente particular del verbo - el infinitivo-, se consideran habitualmente flexivos en mayor medida que derivativos". Lázaro Carreter (1981: 388) however is not of this opinion when he defines the thematic vowel: "Nombre frecuente que se da al determinativo de la raiz, es decir, al elemento que se añade a la raíz para constituir un tema de flexión. Si dicho morfema es una vocal, esta se denomina 
vocal temática". In this definition there are two fundamental issues for the verbal thematic vowel: its morphematic character and its function to join the root in order to constitute together a flection theme.

As already mentioned, the theories in this respect are different and even contradictory. I will examine opinions on its morphematic character, beginning from a negative position presented in one of the first and most knowledgeable contributions on the subject. In Martínez Celdrán's opinion (1975: 169) "la vocal temática no es un morfema, pues no es una unidad gramatical; por su función, podemos ver claro que es un elemento del nivel morfonológico". However, after considering Hockett's position in regards to morphemes as "elementos mínimos con significado individual de las emisiones en una lengua" (Hockett, 1971: 121), and the indivisible minimum morpheme notion as part of the word in accordance to the Praga phonologists, plus the aforementioned quote of Lázaro Carreter (1990: 388), Martínez Celdrán (1975: 166), specifies that "la vocal temática es un elemento vacío de significado, pero que cumple con una función: unirse a la raíz para formar un tema de flexión. Y[...] que[...] es un segmento de la palabra". However, this comment, unfavourable as far as the morphematic value is concerned, is re-examined by Martínez Celdrán following the criterion of Lyons, who conditions the morphematic value to a minimum grammatical unit. According to Lyons, the word can be segmented into morphs, but no into morphemes, and consequently it may be concluded that cannot be at the same time a constitutive segment of the word and a grammatical minimum unit. The appropriate level to place this morph/morpheme relation will be the morph-phonological of Trubetzkoy, within which lexical morphemes and morphs, representative of grammatical morphemes, exist, related, in the present case, through the thematic vowel. This becomes a "característica de todos los morfos representantes de morfemas léxicos verbales" (Mtz. Celdrán, 1975: 169), with the function to select corresponding flectional paradigm.

Antonio Rifón (1997: 11) starts his thematic vowel study analyzing and opposing various authors' positions, like that of $\mathrm{D}$. Corbin, who talking about the infinitive morpheme says that the thematic vowel is a flectional morpheme. To defend it, the French Linguist based her arguments on several facts, resumed here to a couple, such as: a) the listing of verbs in the lexematic dictionaries is presented with the Infinitive; b) the thematic vowel appears always after a derivative suffix, same as the flectional forms. Rifón refutes her by mentioning the permanence of the thematic vowel in the flectional forms, the position of the vowel ahead of the suffix (capt-a-ción), and so on.

Next, Rifón presents: a) the position of Scalisse, interpreting the infinitive suffix as a derivative suffix, creator of verbs from de-nominal or de-adjectival bases; $b$ ) and a similar thought of Varela Ortega, when he says that the thematic vowel is part of the lexematic structure of the verbal theme, profitable for derivative purposes.

Within any position, the most important point is to distinguish whether the verbal thematic vowel has characteristics, typical of derivative morphemes. If the answer is positive it will create new words; if negative, there will exist a conversion derivative process as already explained. After solving this dilemma, the search will start looking for the status corresponding to the thematic vowel.

Several authors reviewed by Rifón, such as Scalisse, Corbin, Varela Ortega maintain that the flectional morphemes are peripheral to the word as compared to the derivative morphemes, with the logical result that the derivative morphemes are maintained in the derived 
series, what does not happen to the flectional morphemes. All this demonstrates that "la vocal del tema forma parte de la estructura lexemática del tema verbal que sirve de base tanto a nuevos procesos derivativos como a los diferentes procesos flexivos" (Rifón, 1997: 14). Same argument cannot be applied to the noun and adjective thematic vowel, which disappears in farther derivations (espin-a > espin-oso; gord-o $>$ gord-ísimo).

There are authors who hold that in the thematic vowel there are aspects typical of flectional but not of derivative morphemes. Rifón (1997: 16-17) presents and analyzes the proposal of Guilbert, who, based on the associative relations, proposes the existence of paradigms, organized after a common base. Whereas in the derivative paradigms the relation is established between different themes, in the flectional ones the relation is applied between different flectioned words of the same theme. The thematic vowel, without belonging to any special dimension whatsoever of the flectional paradigm, is present in all derivations. However the noun thematic vowel is not present, and does not carry grammatical content as the flectional form does. The morphemes of person, number, time and mood are the ones which carry this content. The thematic vowel indicates only the verbal paradigm, according to which the flectional morphemes will be added. This vowel has characteristics akin to the derivative morphemes such as: a) repetition of a derivative element in the same series, (parl-a-ment- $\underline{a}-$ r); b) the change of category of de base; c) capacity to derive verbs from non verbal bases. And simultaneously the verbal thematic vowel implies permanence in all the flectional forms, as it happens -in accordance to Rifon- to the verbal derivative suffixes -iz-, -ific-, -e-, y -ec- already integrated in the verbal lexeme, which only provide a sub-categorization of the meaning, in spite of not being responsible for change of the syntactic value. Because of all this, Rifon concludes that "la función de la vocal del tema es, únicamente, cambiar a verbo la categoría de la base" (Rifón, 1997: 19).

If in previous lines we followed Rifón's work studying the meaning of the thematic vowel, in the next ones we will approach the presentation made by Pena along his studies in this respect, starting from his first contribution of 1991, going through the one of 1993, and finishing with his most important one of 1999.

It is possible to trace back part of these studies, as the author himself says (Pena, 1991: 69) to the II Curso de Gramática Española, Univ. de León. Within the synthetic and dynamic conception of the language, in addition to the derivative affixal processes, there are others that in spite of not being so "invasive", are no less expressive and creative of new words. While leaving aside the most evident addition processes, which are the most productive in the verbal creation, I will only cover the modification processes already mentioned under the forms of: conversion, subtraction and permutation (Pena, 1991: 102), because they can be considered as a reference to analyze the nature of the verbal thematic vowel -a- through its development.

These differences are illustrated with examples, omitted at present, since the important point is the conclusion reached by Pena (1991: 104) saying that in the process of verbal derivation lija > lijar "no hay sustitución, ni sustracción, ni adición de la vocal del tema: el tema es el mismo en el verbo y el sustantivo". Five lines later Pena makes clear that in this example "ocurre el proceso morfológico de la conversión", well defined by Quirk as quoted by Pena (1991: 103): "Conversion is the derivational process whereby an item is adapted or converted to a new word-class without the addition of an affix". In this way, by means of conversion, there are related words formally identical, but belonging to different gram- 
matical classes. Hence the question arises whether the conversion is or not a morphological process, which Pena solves saying with Melcuck that "el cambio afecta a la combinación sintagmática del significante del signo" (Pena, 1991: 109). Given the purpose of the present study devoted to the analysis of the thematic vowel, which appears clearly in the process fich-a $>$ fich-a-r, lij-a $>$ lij-a-r, I may say that Pena has thus far initiated the correct interpretation, but has left the conclusions to be drawn from his coming studies.

One gets the impression that Pena drafted in the previous study the introduction to the coming one dealing, as the title says, on "La formación de verbos en Español: la sufijación verbal" (Pena, 1993). Of all morphological processes to form the significant of a new word, I will select the steps of the simplest process, modification by conversion, in which the base is reproduced. "La sustitución y conversión operan sólo con la vacal del tema en la formación de verbos postnominales y nombres postverbales" (Pena, 1991: 103). The vowel of the theme -a- is the forming element participating in the largest number of bases, it is the most neuter in its meaning, and remains same in noun and verb. To focus the study on the analysis of conversion, I will omit other derivation processes in which the -a- substitutes or adds to other vowels in the process of verbal formation. On the nature of this thematic vowel, and as summary of all above comments, Pena (1999: 4305-4366) presents his latest and most complete information through his contribution in the Gramática Descriptiva de la Lengua Española (Bosque y Demonte (dirs.) 1999).

The analysis of the thematic vowel -a- is to be centered, to understand its nature and function, within the frame of the morphology, furthermore within the word, which can be mono and polymorphemic. The study obviously will gear around the polymorphemic word, considering variable, complex words (with internal structure) omitting the invariable and simple words.

Pena's concept and division is clear (1999: 4313): "Las unidades propias del componente morfológico son las siguientes: 'palabra', 'tema', 'base', y 'morfema' ('raíz o afijo')". The relevant point of this quote is the recognition of the morphemic value to the affix, and to the thematic vowel -a-, as we will see later. It becomes important as well the recognition of the theme like a meaning block: "El 'tema' en el significante de una palabra flexiva es aquel segmento que permanece estable en todas las formas flexivas o, en otras palabras, la unidad que resulta de restar los afijos flexivos"(Pena, 1999: 4313), since the derivative affixes form an integral part of the theme, and may generate in turn themes of related words. The flectional affixes do not form part of the theme and only create different forms from the same word. In summary, "el tema de una entidad flexiva es una entidad abstracta que necesita de los afijos flexivos para figurar como palabra" (Pena, 1999: 4317).

While searching the nature of the thematic vowel through Pena's thought, we should look necessarily into his definition of the word constitutive elements. Initially Pena (1999: 4318) defines morpheme as "la unidad mínima del análisis morfológico y, en definitiva, del análisis gramatical". Although he recognizes that other authors define it as "unidad significativa mínima", "signo mínimo", y "unidad gramatical mínima", he finally will propose that morpheme should be understood as "unidad gramatical mínima".

The application of this concept leads Pena to admit that these grammatical units have the tendency to 'de-semantize' themselves, becoming at times classifiers of the morph construction of the word, as he recognizes to be the case of the verbal thematic vowel. In this way the morphological value of the thematic vowel is restored, because "las unidades 
gramaticales mínimas carentes de significado deben ser reconocidas igualmente en el análisis morfológico porque también forman parte de la construcción formal de la palabra" (Pena, 1999: 4320).

For the morpheme classification, Pena makes use of three criteria: semantic, syntactic and distributional. Paraphrasing Coseriu, Pena presents the dichotomy on which the semantic criterion is based opposing the lexical versus the grammatical; the extra-linguistic reality versus the norm under which the reality is organized; the lexical meaning answering to the what question versus the grammatical meaning to the how question. This distinction could be summarized in the opposition root/flectional affixes, while the derivative affixes would remain in a transition area between the lexical and grammatical fields. "El significado diferente que soportan los afijos derivativos es de naturaleza puramente categorial, pues su función consiste simplemente en categorizar el mismo significado léxico en las distintas clases de palabras: representan distintos 'modos de significar' respecto del mismo significado léxico" (Pena, 1999: 4324).

The syntactic criterion proposed by Pena, is the one originally established by Bloomfield in his article "A set of postulates for the Science of Language" (1926), with the morpheme distinction between free forms (words as minimum linguistic free form) or free morphemes, and bound forms or bound morphemes (affixes, prepositions, conjunctions and connectors in general).

Prior to concluding the study, Pena emphasizes that the thematic vowel has its relevance in the formal constitution of the flection, because it points out to the belonging to a determined conjugation in the case of the Spanish verbs. In summary, Pena has fixed the verbal thematic vowel as an integrating part of the verbal base, within a meaning unit, able to accept flectional forms, with recognized entity as morpheme, and with grammatical semantic value, by transforming into verbal base the root or base to which it is joined.

Lázaro Carreter (1980), talking about the interfixes, with the occasion of his study and analysis of the anti-hiatus Spanish words, deals in parallel with the thematic vowel, with the occasion of its evaluation as morpheme, and consequent lack or possession of semantic value. His statement is clear: "la vocal temática (conjugation vowel) que aparece en las terminaciones del infinitivo español (-ar, -er, -ir), carecería de significado, y no correspondería, por tanto, a morfema alguno" (Lázaro Carreter, 1980: 13). In order to confirm his statement, Lázaro Carreter seeks Hockett's corroboration, for whom cantar is composed by two morphemes cant- $+-r$, since the -a- element would be an empty morph. Next line, in the same study, Lázaro Carreter reassumes the Hocket's later position (1950), rectifying his previous one, and recognizing that a morphemic value can be admitted in the thematic vowel, with a somehow sub-morphemic meaning in the language structure, indicative of its belonging to a determined verbal paradigm. The thematic vowels are from now on integrated "en una categoría especial de morfemas, denominadas señales estructurales" (Lázaro Carreter, 1980: 13), because their meaning is preferably to be defined at the light of the language structure.

The lexical singularity of the morphology, in regards to this particular subject of the -a- thematic vowel, is partially clarified in a Morphology general study written by Soledad Varela (1990) using a different perspective. The Generative Grammar had ground -literally speaking- the morphological components to their minimum elements, and had structured them, after analyzing them with the syntactic and phonological microscope. As an indirect result of the conclusion of this process, the lexicon acquired a new value in its morpholo- 
gical version. Soledad Varela (1990: 33) revises the 'tema' (or base) concept defining it as "una categoría morfofonológica distinta de la palabra", found in compound words inerte, filarmonía,niñera unable to insert itself directly into the phrase chain.

Varela's comments (1990: 33), "el tema es una forma ligada, una semi-palabra, que no contiene afijos flexivos y, por tanto, no está capacitada para actualizarse", are complemented with her following lines pinning down that "se identifica con la raíz verbal acompañada de la llamada "vocal temática". This is a bound form, not subcategorized, and which does not flection. The root, which is as well other bound form, though bearer of semantic value, does not convert itself into one word by means of this morphological process, addition of the thematic vowel. The 'tema' (or base) thus resulting will be a nucleus able to be actualized into a word, by the addition of flectional forms, verbal as well as nominal or adjectival, in order to enter into the syntactical field, following the pertinent syntactic rules, and in turn able to create other new words with the help of non appreciative derivative suffixes.

Milagros Fernández Pérez (1991: 27), describing the realm of the morphology, centers it, in accordance to Anderson whom she quotes, on the foundational theme of the nature and status of the morphemes. Many valid considerations are to be found in her work, of which 1 will emphasize the doubt concerning whether the thematic vowel, of special interest here, is or is not a morpheme. The innovation presented by Fernández Pérez, inspired in Bloomfield, is that the morpheme analysis has to take into consideration the tactic features beyond the associated sememes, reaching the conclusion that there are two types of morphemes: the lexical ones which posses tactical components in addition to lexical, and the grammatical morphemes which have only grammatical tactics, that should become the center of interest for the morphemes. In summary, Fernández Pérez confirms previously expressed criteria admitting that the thematic vowel may be considered endowed at least with grammatical morphemic character.

\subsection{Definition and characteristics of the verbal thematic vowel}

The morphologically speaking 'typically Spanish' - $a$ - thematic vowel has a grammatical meaning content, in spite of the narrow limits of its phonic expression, and therefore, can be distinguished from the derivative and flectional affix. Without belonging to neither one, as a result of its amalgam with the root, the - $a$-constitutes a base of verbal semantic unity of unbreakable expression, although there exists between both elements, root and thematic vowel, a compositional gap, in which an affix, namely an infix, may take place.

Because of all above comments I understand that the thematic vowel is not a suffix, because by function the suffix with its semantic value is applied to form a semantically new word, or different expression of the existing one. This creation or change cannot be achieved by joining to the root the thematic vowel, which lacks semantic meaning. From the point of view of Linguistic Typology, Haspelmath (2002) says that the affixes which form an abstract theme, because lack a clear meaning, are considered at times as empty morphs, with no meaning, but not without function. These affixes in the terminology of Haspelmath (2002: 133), are called: "stem extensions, thematic affixes, or simply thematic vowels", and in the one of Melcuk (2000": 127) "élément thématique".

The principal discussion on the morpheme value of the $-a$ - thematic vowel is favorably solved by considering that it has a verifiable grammatical value in his verbalizing contri- 
bution to the root, making out of it the base of a verb. The conclusion is that the thematic vowel is a morpheme, naturally not a free one, but bound, compositional, and it is neither a derivative nor a flectional suffix.

In summary, the thematic vowel is a sub-morpheme, as Lázaro Carreter (1980: 13) said, bound, compositional, integrated with the root as a grammatical meaning unit, thus constituting together a verbal theme or base. Consequently, this vowel is a grammatical morpheme with grammatical tactics, with a sub-morphemic meaning, but lacking a full semantic value. The thematic vowel confers to the root verbal potentiality, to be actualized by means of flectional suffixes already determined in the assigned selection of the verbal paradigm, and to be relation meaning-wise potentially modified later by means of infixes.

Therefore, any insert inside the verbal theme or base (memor-a-r>memor-iz-a-r, vigor$\left.a-r>v i g o r-i z-a-r^{r}\right)$ will have infix character, because of its function and position. $1^{\text {st }}$ ) The function is to complement the meaning of the root, with a relational semantic value, added to its patrimonial basic meaning, what cannot be achieved by the interfix. $2^{\text {nd }}$ ) The position of the affix will be inside the base, namely by means of an infix, because the suffix is applied after the base.

In this way it is confirmed that the exclusion of the thematic vowel from the derivational and flectional suffixation, demonstrates that the affix inserted into the verbal base is the infix alone.

\subsection{Infix need in the verbalizer de-verbal development of the Spanish language}

Because of the basic morphological structure of the original Spanish verb (root + thematic vowel + flectional suffix), and above comments, we may conclude that it is necessary the infix to achieve a verbalizer de-verbal derivation meaning relation, as unique method for the Spanish language development, either at the formative or evolutive stage.

In the formation of the Spanish language, when its patrimonial verbs, denoting change of state, relation, cause, inchoative, iterative process, etc., show a semantic expression vacuum, it is necessary to create a new term by increasing the meaning support body (the base) with an affix, bearer of the desired relational value. As already seen, the infix will be the only morphological tool qualified to achieve it.

A similar process is followed in the language evolution, in its search for a compact significant and meaning, in order to satisfy style preferences, or needs derived from the expression demand because of the progress of sciences, culture, politics, etc. The development of the potential neologism "se confronta con el conjunto de todos los vocablos y locuciones susceptibles de mantener con él ya sean relaciones de forma, ya sean relaciones de significado" (Díaz Hormigo, 2003: 57). Only if this analysis detects in the lexicon any lack of the relational verbal expression, the process will start coining a new derived term and circulating it freely, because otherwise its immediate blocking would have been triggered (Bybee 1985: 17). The new semantic expression necessarily will be compositional (Frege apud Adele E. Goldberg, 1995: 13).

The meaning of any expression in a language must be function of its immediate constituents, and of the syntactic rules combining them, without need for the time being to delve further into the Montague's syntax/semantics unity. Really, the thesis that the syntax is neither autonomous nor preceding, and that it depends on the semantics is normally 
shared by the majority of the modern grammars, like the cognitive (Cifuentes, 1994: 66) and Dik's functional (Salazar, 1998: 215-6). The summary of these proposals is based on the direct relation between syntactic and semantic composition (Dowty apud A. E. Goldberg, 1995: 14).

Considering that in the present study I do not analyze phrase, but lexical syntagmas, it should be remembered that both constructions syntactic and lexical follow the same pattern. "Lexical constructions and syntactic constructions differ in internal complexity, and also in the extent to which phonological form is specified, but both lexical and syntactic constructions are essentially the same type of declaratively represented data structure: both pair form with meaning" (Goldberg, 1995: 7). The meaning is, therefore, the base for any derived lexical formation,

In the syntactical formation there are two types of fundamental elements: the nominal with an ontological reference, and the verbal with a dynamic and temporal, and often relational reference. Other elements like adjective and adverb act as modifiers of the nominal and verbal/adjectival element respectively. "En el elemento nominal, el sustantivo es la unidad de base que contiene el núcleo semántico-funcional, que le da autonomía sintáctica. Ahora bien, en la estructuración de la forma del contenido, sólo los elementos pertinentes pertenecen a su sustancia significativa en la lengua. Lo posible o accidental tiene que ser actualizado por medio de un modificador" (Urrutia Cárdenas, 1978: 118). In this way the infix as an affix is confirmed as to its semantic role in the de-verbal verbalizing relation derivation, and the need of its application as semantic modifier of the base, in parallel to the syntactic construction.

There are two types of concepts: the basic ones (objects, actions, qualities), normally expressed through independent words and radical elements, which occasionally could imply relation; and the less concrete concepts, relation bearers, which have to be expressed by means of affixes and internal changes in the base. The above mentioned basic language is predominantly related to the sensorial perception, in contrast to the derived language specially connected with the logical perception. This second stage of the language is developed from the first one.

Because of this, I insist in the infixation requirement for the Spanish language in order to carry out the much needed verbalizer de-verbal relational derivative process, since only an element with relational semantic value will be capable to achieve it. The semantic value of the new verb, transformed by the infix, is a relational aspect of the prior radical meaning. On the other hand, the verbalizer de-nominal, de-adjectival, de-prepositional, de-adverbal processes do not need infixation, because they maintain the meaning of the root as is under verbal characteristics. For them it is enough the addition of the verbalizer thematic vowel to the root, plus the flectional suffix to render applicable the verb in the syntactic composition.

Creativity is inherent to the derivative process (Varela Ortega, 1990: 69), because it may generate new words, and even new affixes, in contrast with the limitations of the flectional process, unable to create new lexical entities, since it only transforms the existing ones, or complements them within the paradigms.

When the speaker feels the "necesidad de expresión lingüística de ciertos contenidos conceptuales, sujetos a determinadas relaciones funcionales en el marco de la oración, podría optar por la doble alternativa de su expresión sufijada o independiente - analítica" 
(Vera Luján, 1987: 26). Using without any linguistic partisan intention the term lexicon, we understand it plays a double role in regards to derivation: a) it stores different basic terms for their growth by means of derivation, and; b) with its word cataloguing blocks the creativity to avoid problems of synonyms and homonyms (Vera Luján, 1987: 202).

\section{Conclusion}

The purpose o this theoretical study has been to analyze and determine the existence of Spanish causative infixes, though their meanings may have different semantic values, as it happens with the Spanish affixes in general. The conclusion is that in diachrony the causative Spanish infix has existed, and that in synchrony it is a necessary valuable tool for the language development mainly in the technical, cultural and communicational fields.

\section{References:}

Abraham, W. (1981): Diccionario de terminologia lingüistica actual. Madrid, Gredos.

Alcaraz Varó, E. \& Martínez Linares, M. A. (1997): Diccionario de lingüística moderna. Barcelona, Ariel.

Almela Pérez, R. (1999): Procedimientos de formación de palabras en español. Barcelona, Ariel.

Aranda Ortiz, A. (1990): La expresión de la causatividad en español actual. Zaragoza, Libros Pórtico.

Bajo Pérez, E. (1997): La derivación nominal en español. Madrid, Arco Libros.

Bergua Cavero, J. (2004): Los helenismos del español, Historia y Sistema. Madrid, Gredos.

Bosque, I. (1973): "Sobre la interpretación causativa de los verbos adjetivales", (in) Sánchez de Zavala, V. (ed.) (1976), Estudios de gramática generativa. Barcelona, Labor Universitaria, págs. 101-117.

Bosque, I. y Mayoral, J. A. (1979): "Formación de palabras. Ensayo bibliográfico". Cuadernos Bibliográficos, Madrid, págs. 245-275.

Bosque, I. y Demonte, V. (dirs.) (1999): Gramática Descriptiva de la Lengua Española, 3 Vols., Madrid, Espasa.

Brugman, K. [1887] $\left(1972^{\mathrm{a}}\right)$ : A Comparative Grammar of the Indo-Germanic Languages. $2^{\text {nd }}$ edition, Vol. I, Varanasi, India, The Chowkhamba Sanskrit Series Office.

Brugman, K. [1887] $\left(1972^{\mathrm{b}}\right)$ : A Comparative Grammar of the Indo-Germanic Languages. $2^{\mathrm{ml}}$ edition, Vol. Il, Varanasi, India, The Chowkhamba Sanskrit Series Office.

Brugman, K. [1887] (1972 $)$ : A Comparative Grammar of the Indo-Germanic Languages. $2^{\text {nd }}$ edition, Vol. IV, Varanasi, India, The Chowkhamba Sanskrit Series Office.

Bybee, J. L. (1985): Morphology. A study of the relation between meaning and form. Amsterdam-Philadelphia, John Benjamins Publishing Company.

Cifuentes Honrubia, J.L. (1994): Gramática Cognitiva, Fundamentos críticos. Madrid, Eudema.

Díaz Hormigo, M. T. (2003): Morfologia. Cádiz, Universidad de Cádiz.

DiFabio, E. G. (1990): The morphology of the verbal infix/-Isk-/in Italian and in Romance. (A thesis presented to the Department of Romance Languages and Literatures). Cambridge, Mass., Harvard University.

Dressler, W. U. (1986): "Forma y Función de los Interfijos". Revista Española de Lingüística, 16, 2, págs. 381-395.

Dubois, J. et al. (1992): Diccionario de Lingüistica. Alianza, Madrid.

Encyclopaedia Britannica Online: "Romance languages", Encyclopaedia Britannica, <http://search. eb.com/eb/article?tocId $=74738>$. 
Faitelson-Weiser, S. (1993): "Sufijación y derivación sufijal: sentido y forma". (in) S. Varela (ed.), La formación de las palabras. Madrid, Taurus, págs. 119-161.

Fernández Pérez, M. (1991): "Sobre el concepto de morfema y el ámbito de la Morfología". Verba, Vol. 18, págs. 27-67.

García-Medall, J. (1995): Casi un siglo de formación de palabras del español (1900-1994). Guía Bibliográfica. Valencia, Universitat de València.

García Teijeiro, M. (1970): Los presentes Indoeuropeos con infijo nasal y su evolución. Salamanca, CSIC, Colegio Trilingüe de la Universidad.

Goldberg, A. E. (1995: Constructions, a Construction Grammar Approach to Argument Structure. Chicago-London, The University of Chicago Press.

González Ollé, F. (1992): "Formación de palabras". (in) Holtus,G., Metzeltin, M., Schmitt, C. (eds.)

Lexicon der Romanistischen Linguistik. Vol. VI, 1 Tübingen, Max Niemeyer Verlag, págs. 91-109.

Haspelmath, M. (2002): Understanding Morpholog. London, Arnold (Hodder Headline Group).

Hocket, C. F. (1971): Curso de Lingiḯstica moderna. Buenos Aires, Eudeba.

Lang, M. F. (1997): Formación de palabras en español. Madrid, $2^{\text {nd }}$ ed., Cátedra.

Lázaro Carreter, F. [1953] (1990): Diccionario de términos filológicos. Madrid $3^{\text {rd }}$ ed., $8^{\text {th }}$ Reimp, Gredos.

Lázaro Carreter, F. (1980): "Sobre el problema de los interfijos". (in) Estudios de Lingüistica. Barcelona, Ed. Crítica, págs. 11-26.

Leumann, M. [1926-28] (1977): Lateinische Laut- und Formen-lehre. München, C.H. Beck'sche Verlagsbuchhandlung.

Lloyd, P. M. (1963-1964): "An analytical Survey of Studies in Romance Word Formation". Romance Philology, Vol XVII, N4, May 1964, Berkeley-London-LosAngeles, págs. 736-770.

Malkiel, Y. (1958): "Los interfijos hispánicos". (in) D. Catalán (ed.): Estructuralismo e Historia II, Miscelánea Homenaje a André Martinet. Tenerife, Universidad de La Laguna, págs. 107-187.

Malkiel, Y. (1974), "New Problems in Romance Interfixation (I): The Velar Insert in the Present Tense". Romance Philology, Vol XXVII, N 3, February, Berkeley-London-Los Angeles, págs. 304-355.

Marouzeau, J. (1969): Lexique de la terminologie Linguistique. $3^{\mathrm{e}}$ éd., $3^{\mathrm{e}}$ tir., Paris, Librairie Orientaliste Paul Geuthner, S.A.

Martín Camacho, J.C. (2002): El problema lingüístico de los interfijos españoles. Cáceres, Universidad de Extremadura.

Martínez Celdrán, E. (1974): "A propósito de las leyes diacrónicas de evolución y las sincrónicas de formación", Revista Española de Lingüística, 4, 1, Madrid, págs. 177-195.

Martínez Celdarán, E. (1975): "Estudio morfonológico de la vocal temática en español", Revista Española de Lingüistica, Madrid, 5, 1, págs. 165-175.

Martínez Celdrán, E. (1978): "En torno a los conceptos de Interfijo e Infijo en Español", Revista Española de Lingüística, Madrid, 8, 2, (1978), págs. 447-460.

Mel'cuk, Igor (2000): Cours de morphologie Général, Vol. V. Montréal, Les Presses de l'Université de CNRS,

Montes Giraldo, J. J. (1985): “Los 'Interfijos Hispánicos'. Reexamen con base en datos del ALEC", Anuario de Lingüística Hispánica, Valladolid, Universidad de Valladolid, Vol. I, 1985, págs. 181-189.

Moravesik, E. A. (2000): "Infixation". (in) Booij, G. \& Lehman, C. \& Mugdam, J. (eds.), An International Handbook on Inflection and Word-Formation, Vol. I. Berlin-NewYork, Walter de Gruyter, págs. 545-552.

Moreno Cabrera, J. C. (2003): Semántica y gramática. Sucesos, papeles semánticos y relaciones sintácticas. Madrid, Machado Libros S.A.

Pena, J. (1991): “La palabra: estructura y procesos morfológicos”, Verba, Vol. 18, págs. 69-128.

Pena, J. (1993): "La formación de verbos en español: la sufijación verbal", en S.Varela (ed.), La formación de las palabras. Madrid, Taurus, págs. 217-281. 
Pena, J. (1999): "Partes de la morfología. Las unidades del análisis morfológico". (in) Bosque, ) I. \& Demonte, V. (dirs.) Gramática Descriptiva de la Lengua Española.Vol. III. Madrid, Espasa, págs. 4305-4366.

Pharies, D. (2002): Diccionario Etimológico de los sufijos españoles. Madrid, Gredos.

Portolés, J. (1993): "Sobre los interfijos en español". (in) S.Varela (ed.), La formación de las palabras. Madrid, Taurus, págs. 339-359.

Portolés, J. (1999): "La interfijación". (in) Bosque, I. y Demonte, V. (dirs.), Gramática Descriptiva de la Lenguia Española. Vol. III. Madrid, Espasa, págs. 5041-5073.

Pottier, B. (1953): "Los infijos modificadores en Portugués. Nota de Morfología General". (in) Pottier, B., Lingiüística moderna y Filología Hispánica. Madrid, Gredos, págs. 161-185.

Rainer, F. (1993): "Setenta años (1921-1990) de investigación en la formación de palabras del español moderno: bibliografia crítica y selectiva". (in) Varela S. (ed.), Formación de palabras. Madrid, Taurus Universitaria, págs. 30-70.

Rainer, F. (1999): "La derivación adjetival". (in) Bosque I. y Demonte V. (dirs.), Gramática Descriptiva de la Lengua Española. Vol. III. Madrid, Espasa, págs. 4594-4643.

Real Academia Española (1970): Diccionario de la lengua española. Madrid, 19ª Ed., Espasa Calpe. Real Academia Española (1978): Diccionario de la lengua española. Madrid, $20^{2}$ Ed., Espasa Calpe. Real Academia Española (2001): Diccionario de la lengua española. Madrid, 22a Ed., Espasa Calpe. Rebollo Torío, M. A. (1984): "En torno a los Infijos", Anuario de Estudios Filológicos, Vol VII, Cáceres, Universidad de Extremadura, págs. 311-317.

Rebollo Torío, M. A. (1991): “-Izar". Anuario de Estudios Filológicos, Universidad de Extremadura, Cáceres, Vol XIV, (1991), págs. 405-411.

Rifón, A. (1997): Pautas semánticas para la formación de verbos en español mediante sufijación. Santiago de Compostela, Universidade de Santiago de Compostela.

Saez-Godoy, L. \& Wagner, C. (1992): "Un complejo sufijal productivo: -iz- + -ar en el español de Chile", Estudios Filológicos, $\mathrm{N}^{\circ}$ 27, Valdivia, Universidad Austral de Chile, págs. 29-42.

Saez-Godoy, L. \& Wagner, C. (1993): "Un complejo sufijal productivo: -iz- + -ar en el español de Chile", Estudios Filológicos, $\mathrm{N}^{\circ}$ 28, Valdivia, Universidad Austral de Chile, págs. 97-122.

Salazar García V. (1998): Léxico y teoría gramatical en la lingüistica del siglo XX. Barceiona, Sabir ediciones.

Sapir, E. [1921] (1991): El lenguaje. 12 $2^{\text {a }}$ reimp., México, Fondo de Cultura Económica.

Serrano-Dolader, D. (1999 "La derivación verbal y la parasintesis". (in) Bosque, I. y Demonte, V. (dirs.) Gramática Descriptiva de la Lengua Española, Vol. III. Madrid, Espasa, págs. 4683-4755. Shibatani, M. (ed.) (2001): The Grammar of Causation and Interpersonal Manipulation. Amsterdam -Philadelphia, John Benjamins Publishing Company.

Urrutia Cárdenas, H. (1978): Lengua y discurso en la creación léxica. Bilbao, Planeta/Universidad de Deusto.

Varela Ortega, S. (1990): Fundamentos de Morfología. Madrid, Síntesis.

Vera Luján, A. (1987): Aspectos sintáctico-semánticos en la sufijación. Murcia, Universidad de Murcia. 